\title{
Adjustment strategies used by hill country farmers
}

\author{
J.R. Nicholls', D.I. Gray', A. Wright' \\ and P. A.G. Fraser*
}

'Department of Agricultural and Horticultural Systems Management, Massey University, Palmerston North

${ }^{2}$ MAFTech, Dannevirke

ABSTRACT A number of "progressive" farms in the Pongaroa district were surveyed in 1989 to learn how they had adjusted to deteriorating economic conditions over the period $1984 / 85$ to $1987 / 88$. The results from 20 case studies showed that the farmers had been successful in maintaining productivity. Total farm income per stock unit had increased by $1 \%$ and farm surplus by $8 \%$. Adjustments featured improved performance from existing sheep and cattle enterprises, with greater emphasis on wool and dry stock. Diversification to new enterprises had not been an important change for any farmer. Expenditure on fertiliser, feed, repairs and maintenance, and vehicle expenses declined, and monitoring and control of expenditure increased. A comparison of farms that had maintained fertiliser applications with those that had not applied fertiliser showed little difference in gross farm income. Farmers were confident about the future viability of their farms, given a reduction in interest rates. A joint MAF/Federated Farmers' extension exercise in 1985 had been very successful in preparing farmers for the difficult period since 1984/85.

Keywords farm adjustment, farm survey, Pongaroa district, hill country productivity, fertiliser use

\section{INTRODUCTION}

In recent years farmers have faced increased uncertainty as deregulation of the economy has added to the normal problems of coping with seasonal variability. The dismantling of the support structure for agriculture began in 1984 but was buffered in 1984/85 owing to a $20 \%$ devaluation of the New Zealand dollar, a relatively good climatic year and the retention of transitionary SMPs. It was estimated that in 1984/85 farming received $\$ 1000$ million in subsidies of which $\$ 270$ million were in the form of SMPs. In 1985/86, the removal of SMPs and revaluation of the New Zealand dollar saw lamb prices fall $47 \%$, mutton $63 \%$, beef $27 \%$ and wool $9 \%$. This effect was further compounded by removal of input subsidies, freeing up of interest rates, a floating exchange rate, and a return to a high rate of inflation with the removal of the price freeze
(NZMWBES). Farmers had moved from a protected to a totally free-market environment in 12 months.

Already some farm businesses have failed through inability to adjust successfully to rapidly changing conditions. The problem is particularly acute for hill country farmers because of limited production options. As part of an investigation into adjustment strategies used by hill country farmers, a survey of the Pongaroa district was conducted to learn how farmers have adjusted to changing conditions.

The Pongaroa district was chosen as it had a good information base from earlier MAF surveys carried out in 1949150 (Woods 1951) and 1978/79 (Shepherd \& Arthur-Worsop 1980). In addition MAF and Federated Farmers had undertaken an extensive budgetary survey in Southern Hawke's Bay in 1985 , to alert farmers to forthcoming problems.

\section{THE SURVEY}

The area surveyed corresponded to the Akitio County of the 1949150 and 1978179 surveys, and was estimated to contain about 125 sheep and beef farms. Twenty-two farms were selected from a group identified as "progressive" at the time of the 1985 MAF/Federated Farmers' exercise. This group comprised farmers who appeared to be willing to make soundly based management changes, and who had cooperated in providing information in the past. They were visited in early 1989 and information was collected on current levels of productivity and profitability, changes in management practices since 1984185, and intended changes from 1988/89. Twenty farmers were able to provide full physical and financial data. After the case study survey a postal survey of remaining farms in the district was carried out. Results from this were not available in time to include in this paper.

\section{RESULTS AND DISCUSSION}

The farmers' average age was 43 years, and most had one or more dependants. All were owneroperators and had been responsible for the financial management of their farms for an average of 14 years. Seasonal conditions after the excellent autumn of 1984 are summarised in Table 1. An additional feature of the period was the prolonged freezing works stoppage in the autumn of 1986. Physical production, income and expenditure data 
from the 20 survey farms are given in Table 2 . Percentage changes from $1984 / 85$ are shown in brackets.

Table 1 Seasonal conditions in the survey region

\begin{tabular}{|c|c|c|c|}
\hline Season & $1984 / 851985 / 86$ & $\begin{array}{l}\text { ear } \\
1986 / 8\end{array}$ & $71987 / 88$ \\
\hline Winter & Mild $\quad$ Mild & Cold & Mild \\
\hline Spring & Good & Cold & Good \\
\hline Summer & Growth & Dry & Dry \\
\hline Autumn & Average & Good & Excellent \\
\hline Lambing $\%^{\prime}$ & 103 & 82 & 99 \\
\hline Stocking rate ${ }^{1}$ su/ha & 10.1 & 10.2 & 10.3 \\
\hline
\end{tabular}

\section{PHYSICAL PRODUCTION}

Total stock units per farm in $1987 / 88$ were $2 \%$ greater than in 1984/85. Individual farms ranged from a decrease of $19 \%$ to an increase of $35 \%$. The mean stocking rate of $10.3 \mathrm{su} / \mathrm{ha}$ in $1987 / 88$ corresponds to the "readily attainable" stocking rate identified in the 1978/79 survey, at which time the average stocking rate was estimated to be $8 \mathrm{su} / \mathrm{ha}$.

Number of breeding ewes wintered per farm decreased by $5 \%$, but this was partly offset by an increase in the number of hoggets wintered. In addition, a greater proportion of hoggets were wintered to supply contract markets. Management changes associated with carrying increased numbers of hoggets were later lambing (1987 mean lambing date, mid-August) and mating for two rather than three cycles. Future intentions of farmers would see a further decline in ewe numbers.

Wool production per ssu increased by $4 \%$, and the range in production suggests scope for improved performance on some farms isconsiderable. There is a trend to change from full wool and second shearing to an 8-month policy. Reasons for the change were to produce a more even cash flow (for full wool shearing), and to reduce shearing costs and improve prices (for second shearing). Nine farmers

Table 2 Physical and financial data for survey farms

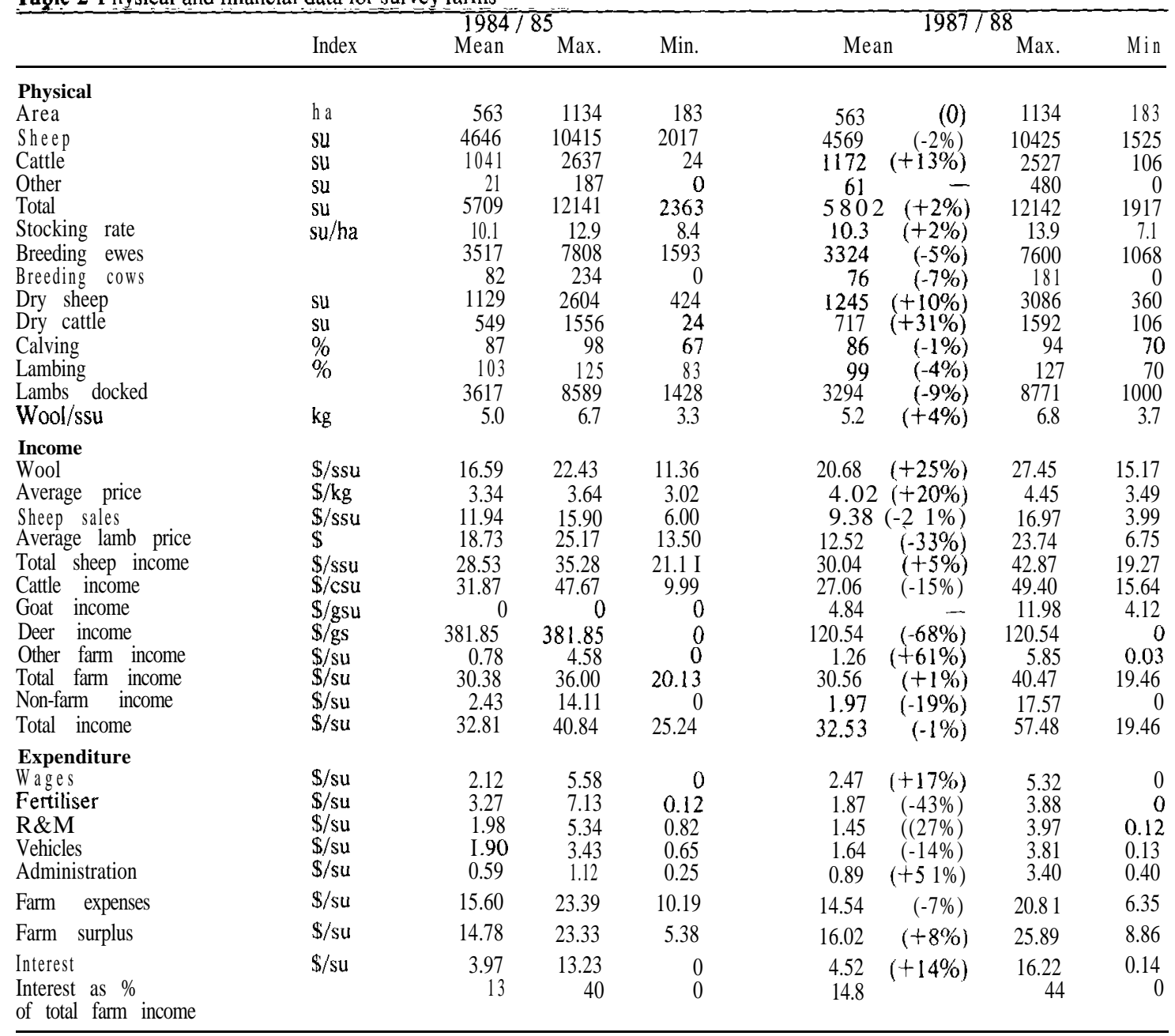


expressed interest in running wethers for wool production, or in Merino sheep for fine wool production.

Fifteen farmers ran breeding cows in $1987 / 88$, compared with 16 in 1984185. Breeding cow numbers decreased by $7 \%$ but $75 \%$ of farmers had increased the number of dry cattle, most by introducing or increasing bull beef. Four farmers now leave their beef calves entire. There was a trend to selling older cattle at heavier weights as a means of increasing returns and market flexibility. Only three farmers expected to increase cattle numbers, and two of these farmed bull beef.

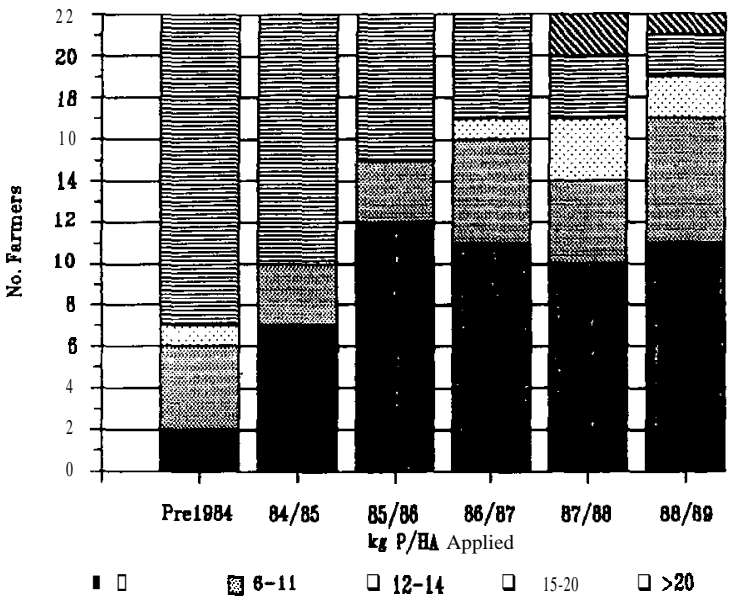

Figure 1 Number of farmers applying fertiliser and rates of application.

Most farmers believed they were monitoring their pastures, but few made use of formal feed budgets and none. were regularly updating budgets in association with pasture monitoring. More farmers were now using scales, with $68 \%$ monitoring liveweights, primarily of animals coming up to slaughter. Number of farmers weighing fleeces declined.

\section{INCOME AND EXPENDITURE}

Total farm income per stock unit increased by $1 \%$ : the large increase in wool income being offset by a similar decrease in income from sheep sales. In $1987 / 88$, wool contributed $50 \%$ of total income compared with $41 \%$ in 1984185 . Sources other than sheep and cattle contributed less than $4 \%$ of total farm income in $1987 / 88$. Goats or deer provided small amounts of income on four farms. Non-farm income amounted to more than $\$ 18,000$ in $1987 / 88$ for seven farmers and comprised mainly off-farm work, investment income and sales of assets.

Farm expenditure decreased by $7 \%$ in $1987 / 88$ compared with 1984185, with large reductions in the discretionary items of fertiliser, $\mathrm{R} \& \mathrm{M}$, and vehicle expenses. Administration showed the greatest percentage increase. The overall effect was that farm surplus increased $8 \%$ from $\$ 14.78 /$ su to $\$ 16.02 /$ su. Interest payments accounted for nearly $15 \%$ of total farm income per stock unit in $1987 / 88$ compared with $13 \%$ in 1984185 , and was the expenditure item of most concern to farmers. Interest accounted for more than $20 \%$ of total farm income on 10 farms, a situation regarded as unsustainable in the long term (Taylor 1985). Control of expenditure has become an important component of management with all farmers planning to reduce their need for seasonal finance. One third of the farmers used computers to assist financial planning and control.

\section{FERTILISER}

Fertiliser use in New Zealand declined dramatically a f t e r 1984/85 (NZMWBES 1987/88). T h e number of survey farmers not applying fertiliser peaked at 12 in 1985/86 and has remained at about $50 \%$. In addition the rate of phosphate application has declined (Figure 1). Eight of the survey farms had applied significant amounts of fertiliser (14-25 units of $\mathrm{P} / \mathrm{ha}$ to at least half the farm) in three of the four years from 1984/85. Four farmers had applied little or no fertiliser during this period. A comparison between these two groups (Table 3) shows that withholding fertiliser is associated with farms with high debt servicing costs, and as yet has had little effect on gross farm income. Nine farmers had noticed effects of reduced fertiliser in terms of later spring and autumn flushes, less clover, more difficult lamb fattening, and reversion on marginal or recently developed blocks.

Table $31987 / 88$ data for farms with different fertiliser histories ${ }^{a}$

\begin{tabular}{|c|c|c|c|c|}
\hline & & & $\begin{array}{l}\text { Fertiliser } \\
\text { Nil } \\
+ \text { farms) }\end{array}$ & $\begin{array}{l}\text { application } \\
\text { Regular } \\
(8 \text { farms })\end{array}$ \\
\hline Area & ha & 376 & & 591 \\
\hline Stock units wintered & & 3527 & $(-5 \%)$ & $(+6 \%)$ \\
\hline Lambing rate & $\$$ & 94 & $(-3 \%)$ & $(-4 \%)$ \\
\hline Wool/ssu & $\mathrm{kg}$ & 5.2 & $(+4 \%)$ & $5.0(+2 \%)$ \\
\hline $\begin{array}{l}\text { Total sheep } \\
\text { income/ssu }\end{array}$ & $\$$ & 28.32 & $(-7 \%)$ & $28.86(+1 \%)$ \\
\hline Cattle income $/ \mathrm{cm}$ & $S$ & 26.41 & $(-9 \%)$ & $(-23 \%)$ \\
\hline $\begin{array}{l}\text { Gross farm } \\
\text { income } / \mathrm{su}\end{array}$ & $\$$ & 28.73 & $(-6 \%)$ & $29.40 \quad(-4 \%)$ \\
\hline Fertiliser exp./su & $\$$ & 0.17 & $(-92 \%)$ & $(-28 \%)$ \\
\hline Farm exp./su & $\$$ & 10.68 & $(-24 \%)$ & $(-6 \%)$ \\
\hline Farm surplus & $\$$ & 18.05 & $(+10 \%)$ & 15.73 \\
\hline Interest/su & $\mathbf{S}$ & 10.11 & $(+25 \%)$ & $(-4 \%)$ \\
\hline
\end{tabular}

a(\%) change since 1984/85

There were considerable changes in the form of fertiliser used and the proportion of the farm topdressed, as farmers attempted to get best value for fertiliser expenditure. The number of farmers using split dressings increased from three in 1984/ 85 to seven in 1988/89. More farmers are using either reactive phosphate rock or high analysis 
fertilisers in place of straight superphosphate. A number of farmers used nitrogen to generate cattle feed. Most farmers intend to apply fertiliser in the future if they can afford it.

\section{CONCLUSIONS}

The farmers surveyed have, on average, been successful in maintaining productivity over the period $1984 / 85$ to $1987 / 88$. Adjustment strategies have involved maintaining high levels of productivity and profitability from existing sheep and cattle enterprises with reduced inputs, rather than substantial changes to production systems. Diversification to new enterprises has not been a feature of the survey farms.

Future opportunities are seen by farmers to lie in improved performance of present systems, and gradual changes in response to market demands. Monitoring of farm systems, particularly of liveweights of trading stock, and of cash flows, are now important components of management. Farmers were confident about the future, providing Government policies were successful in reducing interest rates.

We gained the impression that a major reason for successful adjustment on the farms surveyed was the extension exercise by MAF and Federated Farmers in 1985. This had provided farmers with very good information about forthcoming problems, and the means to cope with them.

Acknowledgements To the farmers who co-operated in the survey. Financial support for this study was provided by the Rural Policy Unit of MAFTech, and the Massey University Research Fund.

\section{REFERENCES}

MAFTech. Farm Monitoring Reports. North Central Region. 1984 to 1988 .

N.Z. Meat and Wool Board's Economic Service. Annual Reviews of the Sheep and Beef Industry. 1984-85 to 1987/88.

Shepherd, A.A.: Arthur-Worsop, M. 1980. Factors affecting agricultural production from a group of hill country farmers comprising Akitio County. Proceedings NZ Branch oj' Australian Agricultural Economics Society. RW.M Johnson and P.G. Bushnell (Eds). pp 43-62.

Taylor, N.W. 1985. Some aspects of farm finance in the sheep and beef industry, 1985. Paper No. 1913. N.Z Meat and Wool Board's Economic Service.

Woods. L.W. 1951. Developing Marginal Lands. Bulletin No. 339. N. Z. Depantnent of Agriculture. 